\title{
POŠTA
}

TELEKOMUNIKÁCIE A

ELEKTRONICKY OBCHOD

\section{PARCIÁLNE ČLENENIE MARKETINGOVÝCH STRATÉGIÍ}

\author{
Michal Martinka, Iveta Kremeňová*
}

\section{Úvod}

Strategický riadiaci proces je súborom činností a rozhodnutí, ktoré vedú $\mathrm{k}$ formulovaniu plánu podniku a jeho realizácii. Je podstatnou súčast'ou aktivít každého moderného podniku (či už je malý alebo vel'ký), ktorý pôsobí v trhových podmienkach. Jeho úlohou je dlhodobé usmerňovanie činností podniku tak, aby bolo naplnené jeho poslanie a zaistené ciele. Zahŕňa klúčové rozhodnutia a kl'účové kroky, realizované vrcholovým vedením podniku i vedením jednotlivých podnikových útvarov s jednotnou úlohou: vyvinút' komplexnú dlhodobú stratégiu pre prežitie a hospodársky rast (čo znamená vytvorit' perspektívu podniku ako celku - jednotnú perspektívu všetkých jednotiek ako funkčných, tak aj prevádzkových - a riadit' ich rovnakým smerom). Vzhl'adom na aktuálnost' problematiky v oblasti stratégií, sa článok venuje otázkam základného parciálneho členenia stratégií.

V literatúre sa v súvislosti s členením marketingových stratégií najčastejšie uvádzajú nasledovné strategické parciálne prístupy:

- podl'a Ansoffa,

- podl'a Portera,

- podl'a Kotlera.

V d’alších častiach článku si postupne predstavíme jednotlivé prístupy.

\section{1. Členenie marketingových stratégií podl’a Ansoffa}

Zvýšenie príjmu dosahujú podniky využitím viacerých možností, ktoré vznikajú využívaním súčasných i nových výrobkov na súčasných i nových trhoch. Niektoré podniky sa riadia strategickým prístupom, definovaným Ansoffom, ktorý je uznávaným odborníkom a autorom stratégií pre výrobok a trh (a v súčasnosti už tiež klasikom problematiky - názory na tieto otázky vyslovil v 60 . rokoch 20 . storočia a toto zameranie je i dnes pre podniky významné).

Ansoff ukazuje vo vzájomných súvislostiach dva prvky:

$>$ marketingové ciele, vyjadrené pomocou dvoch dimenzií - výrobkov a trhov,

$>$ marketingové stratégie, reprezentované v základnej zostave štyrmi možnost’ami.

Jeho matica (tab. č. 1) dáva do vzt’ahu trhy znázornené v riadkoch s výrobkami, ktoré majú svoje miesto v stĺpcoch. Matica je teda rozdelená na časti predstavujúce výrobky a trhy nové a výrobky a trhy súčasné. Pole matice prezentujú strategické alternatívy vhodné pre dosiahnutie rastu v oblasti podnikania daného podniku. Jedná sa o výhradne rastové stratégie. Ansoff neuvažuje o stratégiách ústupu.

\footnotetext{
* Ing. Michal Martinka, Kinex Zilina, externý doktorand F-PEDAS, Doc. Ing. Iveta Kremeňová, PhD., Katedra spojov, F-PEDAS, Žilinská univerzita v Žiline tel.: 041/5133100, 101- sekr., fax: 041/5655615

e-mail: MMartinka@kinex.sk, Iveta.Kremenova@fpedas.uniza.sk
} 
Tab. č. 1. Matica strategických alternatív vhodných pre dosiahnutie rastu podniku

\begin{tabular}{|c|c|c|}
\hline \multirow{2}{*}{ Trhy } & \multicolumn{2}{|c|}{ Výrobky } \\
\cline { 2 - 3 } & súčasné & nové \\
\hline súčasné & 1. penetrácia trhu & 3. rozvoj produktu \\
\hline nové & 2. rozvoj trhu & 4. diverzifikácia \\
\hline
\end{tabular}

Ak sa pozrieme na Ansoffovu maticu z hl'adiska existujúcich výrobkov a súčasných trhov, tak len stratégia penetrácie trhu -sa zaoberá súčasnými trhmi a existujúcimi výrobkami. Ostatné strategické smery vychádzajú zo skutočnosti, že podnikové ciele už nie je možné definovat' $\mathrm{v}$ rámci existujúcich výrobkov a v podmienkach súčasných trhov. Vzhl'adom k rýchle sa meniacim potrebám zákazníkov sú vedl'a existujúcich výrobkov nevyhnutné i nové, vhodnejšie výrobky, uplatňujúce sa nielen na súčasných trhoch, ale i na trhoch nových a tým vzniká i nevyhnutnost' formulovania d'alších vhodných stratégií pre ziskovú existenciu podniku (tab. č. 2).

Tab. č. 2. Ďalšie vhodné stratégie pre ziskovú existenciu podniku

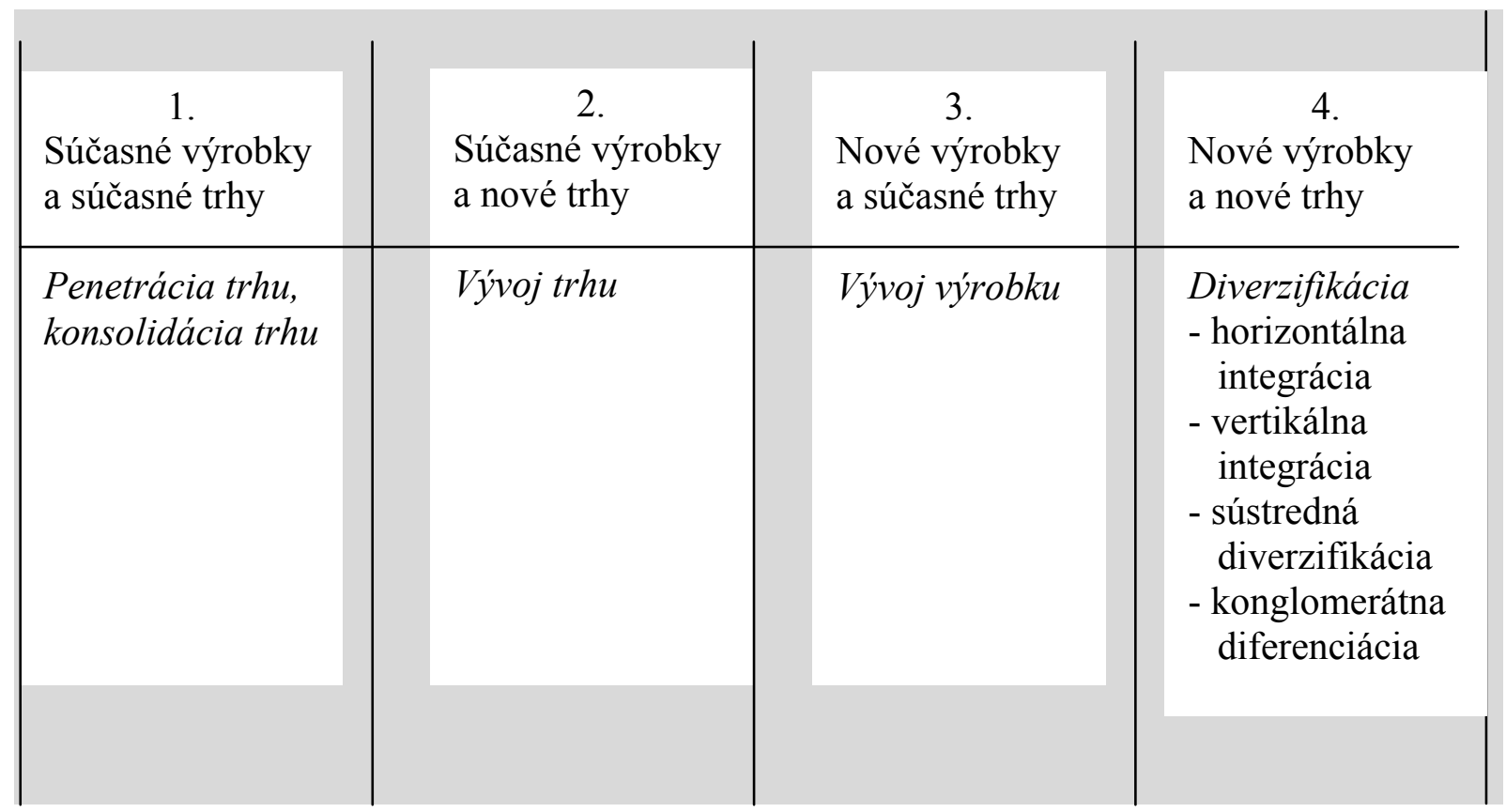

Ďalej si priblížime stručnú charakteristiku stratégií uvedených v tabul'ke č.2.

\subsection{Stratégia penetrácie}

Podnik sa snaží predat' existujúcim zákazníkom viac existujúcich, prípadne inovovaných služieb. Stratégia penetrácie je vhodná a často aplikovaná vo sfére služieb cestovného ruchu, služieb telekomunikácií alebo služieb využitia vol'ného času. Uvedené služby, ale aj d'alšie, umožňujú zákazníkom spotrebúvat' viac, častejšie, prípadne na iný účel 
ponúkané služby alebo výrobky. Penetrácia trhu neznamená ani zmenu trhu, ani zmenu služby či výrobkov, ale predovšetkým dôraznejšie a pôsobivejšie zameranie na súčasné trhy s existujúcimi výkonmi.

\subsection{Stratégia rozvoja trhu}

Podnik ponúka produkt iným segmentom. Zvýšenie predajného obratu možno dosiahnut' napríklad predajom existujúcich výkonov v d'alších geografických oblastiach, identifikáciou nových trhových segmentov $\mathrm{v}$ bežných predajných oblastiach, nájdením nových spôsobov použitia existujúceho výkonu na nových trhoch, zvýraznením pozície súčasných výkonov na nových trhoch, napríklad posilnením značky alebo image a pod.

\subsection{Stratégia rozvoja produktu}

Podnik ponúka existujúcim zákazníkom inovované alebo nové produkty. Stratégia vychádza zo zmeny výkonu a zo zachovania jeho predaja na súčasných trhoch. Stratégia je úspešná na trhu, na ktorom má poskytovatel' vel’a verných zákazníkov.

Výkony si vyžadujú neustálu inováciu. Táto umožňuje výrobcom udržat' si náskok alebo dolíšenie od konkurencie.

\subsection{Stratégia diverzifikácie}

Podnik ponúka nové služby novým skupinám zákazníkov. Táto stratégia predstavuje zo všetkých stratégií rastu najnákladnejšiu a najriskantnejšiu stratégiu. Zvlášt', ak rozvoj nových výkonov smeruje do výrazne odlišných oblastí. Stratégia je vel'mi pôsobivá, ale rovnako značne riskantná, pretože podniky väčšinou nemajú ani výrobné, ani marketingové skúsenosti (nový výrobok, nový trh), ktoré by mohli použit'. Dostávajú sa do celkom odlišných trhových oblastí so značkami do tejto doby tu neznámymi. Dochádza k objavovaniu a využívaniu celkom nových podnikatel’ských príležitostí. [3]

\section{2. Členenie marketingových stratégií podl’a Portera}

Pre dosiahnutie podnikových ciel'ov organizácie najskôr vyjadria celopodnikový strategický smer platný pre celú organizáciu - najčastejšie sú používané stratégie vychádzajúce z Porterovho prístupu, ktoré je možné použit' bez rozsiahlych problémov a t'ažkostí vo väčšine podnikov, a to bez podstatných ohl'adov na konkrétne výkony a príslušné odvetvie alebo odbory. Jedná sa:

- $\quad$ o dosiahnutie postavenia najefektívnejšieho výrobcu v odvetví alebo odbore. Pokial' sa podnik stane vodbore alebo odvetví výrobcom s najnižšími nákladmi, bude pravdepodobne dosahovat' väčšie zisky .

- $\quad$ o výraznú diferenciáciu v porovnaní s konkurenčnými firmami. Pokial' podnik bude významne diferencovat' svoj výrobok takým spôsobom, že zákazník túto diferenciáciu rozpozná a ocení - a bude ochotný zaplatit' vyššiu cenu - potom pravdepodobne bude dosahovat' vyšší zisk

V súlade s vyššie uvedenými podnikovým strategickým smerom volia manažéri marketingové stratégie vedúce $\mathrm{k}$ zabezpečeniu marketingových úloh. Tie sú väčšinou v určitom vzt'ahu k zisku (rozdielnym spôsobom a v rozdielnej miere) a podniky sa snažia bud':

- zvýšit' príjmy, 
- znížit' výdaje,

- alebo skúšajú oboje.

Stratégie, ktorá prezentujú základnú schému postupu podniku pre dosiahnutie ciel’ov sú nazývané generickými stratégiami. Manažéri vychádzajú pri ich odvodzovaní väčšinou z prístupu M. Portera, ktorý je - jednoducho povedané - založený na myšlienke, že dlhodobo udržatel'ná konkurenčná výhoda je základom výkonnosti podniku, teda že strategický smer je potrebné odvodit' od dosiahnutel'nej konkurenčnej výhody. Pre budúcnost' najmä pri rýchlych zmenách prostredia nie je možné všeobecne počítat's dlhodobou konkurenčnou výhodou.

Porter definuje 3 základné konkurenčné stratégie:

\subsection{Stratégia diferenciácie}

Môže byt' založená na rôznych základoch. Medzi najdôležitejšie patrí kvalita, rýchla a neustála inovácia, dodacie podmienky, pri službách miesto dodania, personál poskytujúci služby, či ich cena. To všetko umožní ponúknut' zákazníkovi vyššiu hodnotu ako konkurencia. Stratégiu diferenciácie uplatňujú vel'ké podniky poskytujúce služby (letecké spoločnosti, banky, poist'ovne), no úspešne ju môžu uplatnit' aj malí, lokálni výrobcovia, alebo poskytovatelia služieb (napr. špecializovaná pekáreň, 3D kino a pod.). Stratégiu diferenciácie uplatňujú aj výrobné podniky, ktoré svoju ponuku diferencujú práve rozšírením svojho výrobku o služby naň viazané. Diferenciácia (odlišnost') by mala byt' taká, aby ju konkurencia nemohla l'ahko napodobnit'.

\subsection{Stratégia nízkych nákladov (nákladového vodcovstva)}

Stratégia je založená na vel'kom trhovom podiele alebo na niektorom vnútornom zdroji nízkych nákladov (lacno nakupované vstupy, vysoká produktivita, nízke mzdové náklady, jedinečné postupy). Vedúcu pozíciu v nákladoch možno dosiahnut' nielen znižovaním ceny, ale aj zvyšovaním objemu predaja pri udržaní danej ceny. Nízke náklady sa dajú dosiahnut' napr. nízkonákladovou distribúciou (napr. pomocou internetu).

\subsection{Stratégia sústredenia (focus)}

Býva častejšie aplikovaná menšími podnikmi, ktoré si vyberú relatívne malú čast' trhu s osobitnými požiadavkami. Uplatňujú ju podniky, ktoré nemajú dostatok zdrojov na to, aby konkurovali vel'kým podnikom. Podstatou stratégie je aj odlíšenie svojej ponuky, relatívne úzkej, od ponuky konkurencie a ponuka relatívne úzkemu trhovému segmentu alebo ponuka na pomerne malom území. Odlíšenie musí predstavovat' podstatu konkurenčnej výhody. [1]

\section{3. Členenie marketingových stratégií podl’a Kotlera}

Kotler v rámci parciálneho prístupu vymedzuje štyri typy stratégií. Základným kriteriálnym hl'adiskom je postavenie podniku na trhu (vel'kost' trhového podielu v odvetví alebo odbore). Prvou stratégiou je stratégia trhového vodcu, druhou stratégia trhového vyzývatel'a, tret’ou je stratégia trhového nasledovatel'a a štvrtou stratégiou je stratégia obsadzovania trhových medzier (výklenkov). 


\subsection{Stratégia trhového vodcu}

Vodcom trhu je podnik, ktorého dominanciou je najväčší podiel na danom trhu. Trhovým vodcom je napríklad Procter and Gamble, General Motors alebo McDonald's. Prianím trhového vodcu je dominantné postavenie zachovat' alebo posilnit' - obstát' na vedúcom mieste. (Ciel’om stratégie je previest' prvú pozíciu trhu do vhodnej konkurenčnej výhody). Vodcovia sa vo vel'a prípadoch tešia dobrej povesti na trhu (všeobecne to ale neplatí - môžu, ale nemusia mat' dobrú povest'). Ich trhové postavenie je ale ostatnými účastníkmi trhových operácií rešpektované.

Aké sú najpravdepodobnejšie strategické zámery trhového vodcu:

a. Chránit' súčasný trhový podiel v rámci terajšieho trhu (ide o obranu terajšej pozície, teda udržanie postavenie vodcu. Strategický zámer sa zakladá na defenzívnom prístupe. Dobrá obrana st’ažuje novým podnikom vstup na trh a znamená udržanie príslušnej konkurenčnej výhody).

b. Zväčšit' celkový trh (Podnik s dominanciou v podiele na trhu získa pravdepodobne viac, ak sa zväčší celkový trh).

c. Zvýšit' trhový podiel v rámci terajšieho trhu.

\subsection{Stratégia trhového vyzývatel'a}

Táto stratégia je vhodná pre firmy, ktoré majú slabšie postavenie ako vodca trhu, väčšinou zaujímajú druhú, prípadne tretiu pozíciu za trhovým vodcom a sú ochotné a pripravené vodcu prenasledovat' a bojovat' za silnejšie postavenie na trhu. Je to ofenzívny typ strategického prístupu. Ciel'om je zvýšit' podiel trhu, a to bud' na úkor vodca trhu alebo na úkor rovnako vel'kých, menších a malých firiem, ktoré fungujú na rovnakých trhoch.

Kotler odporúča 5 možných útočných stratégií:

a. Stratégia priameho (čelného) útoku - útočník všetkými nástrojmi marketingového mixu napáda pozície vyzývaného (hlavne jeho silné stránky).

b. Stratégia bočného útoku - útočník napáda všetky slabé stránky vyzývaného.

c. Stratégia obkl'účenia - útočník napáda vyzývaného zároveň na niekol'kých miestach.

d. Stratégia obchvatného útoku - zavedenie nových technologických procesov vytlačí z trhu terajšie výrobky, rozšíri sa trh a zvýši sa predaj.

e. Stratégia partizánskych útokov - nepredvídané útoky v nepravidelných intervaloch.

\subsection{Stratégia trhového nasledovatel'a}

Podnik uzná trhového vodcu a uzná, že nemá zmysel získavat' jeho zákazníkov. Skôr sa ho snaží napodobňovat', pričom chce dosiahnut' aj určitú odlišnost', ktorá vyhovuje určitej zákazníckej skupine.

Kotler uvádza 4 základné smery vhodné pre trhového nasledovatel'a:

a. Stratégia napodobňovania - predpokladá nielen napodobňovanie ale aj určité odlíšenie.

b. Stratégia upravovania - predpokladá úpravu a zdokonal'ovanie výkonov, ktoré boli prebrané od trhového vodcu.

c. Stratégia skrytého konkurenta - nasledovatel' kopíruje výrobky vodcu a nelegálne ich predáva.

d. Stratégia parazita - predstavuje napodobeniny výrobkov vodcu s nepatrnými odlišnost’ami. Parazit predáva tieto imitácie za nižšie ceny. 


\subsection{Stratégia obsadzovanie trhových medzier}

Podniky s touto stratégiou vyhl'adávajú trhové medzery. Vôbec sa nevenujú celému trhu alebo vel'kým trhovým segmentom. Tieto podniky majú určitú špecifickú schopnost', ktorá je atraktívna pre určitú malú čast' trhu, ale nie je atraktívna pre vel'ké alebo väčšie podniky.

Trhová medzera by mala byt' dostatočne vel'ká pre podnik, ktorý sa o tento priestor zaujíma, mala by tu byt' dostatočná kúpna sila, možnost' d'alšieho rastu a dostatočný ziskový potenciál. Mala by zapadat' medzi schopnosti firmy a zároveň by mala byt' mimo sféru záujmu vodcov trhu. [2]

\section{Záver}

Podnik si po vytýčení ciel'a môže vybrat' z rôznych druhov stratégií, ktoré mu zabezpečia jeho dosiahnutie. Dokonca sa nemusí upriamit’ na jednu vybranú stratégiu, ale môže si zvolit' kombináciu rôznych. Dôležité je hlavne to, čo je pre daný podnik, pri daných podmienkach najvýhodnejšie.

\section{Literatúra}

[1] KUPKOVIČ, M. A KOL.: Podnikové hospodárstvo, Sprint, Bratislava, 2002, 461 str., ISBN 80-88848-93-8

[2] HORÁKOVÁ, H.: Strategický marketing, 2. rozšírené a aktualizované vydanie, Grada Publishing a.s., Praha 2003, 204 str., ISBN 80-247-0447-1

[3] ĎAĎO, J., PETROVIČOVÁ, J., KOSTKOVÁ, M.: Marketing služieb, EPOS, Bratislava, 2006, 296 str., ISBN 80-8057-662-9

[4] KREMEŇOVÁ, I., ROSTÁŠOVÁ, M..: Marketing v službách, Marketingový informačný systém, EDIS, ŽU v Žiline, 2006, ISBN 80-8070-358-2

[5] ROSTÁŠOVÁ, M., KREMEŇOVÁ, I.: Marketing v službách, Algoritmy marketingových činností, EDIS, ŽU v Žiline, 2006, ISBN 80-8070-355-8

\section{Grantová podpora}

Článok vznikol pre podporu projektu VEGA - Vplyv výberu efektívnej stratégie na riadenie konkurencieschopnosti podniku v rámci liberalizácie poštových trhov. 